\title{
Taxonomic novelties in the genus Campylospermum (Ochnaceae)
}

\author{
P. Bissiengou ${ }^{1-3^{*}}$, L.W. Chatrou ${ }^{2}$, J.J. Wieringa ${ }^{1,2}$, M.S.M. Sosef ${ }^{1,2}$
}

Key words
Africa
Campylospermum
conservation
Gabon
Gomphia
IUCN Red List
Ochnaceae
Ouratea
taxonomy

\section{INTRODUCTION}

The genus Campylospermum has about 50 species occurring in continental Africa, Madagascar, extending east to China and the Malesian region. It belongs to the subfamily Ochnoideae, tribe Ochneae, subtribe Ouratinae (Kanis 1968). This subtribe contains three other genera: Rhabdophyllum Tiegh. (Africa, 8 species), Ouratea Aubl. (Neotropics, c. 140 species) and Idertia Farron (Africa, 3 species; Farron 1985, Kanis 1968, Sastre 1988, Sosef 2008). In contrast to Ochnaceae specialists who recognized these genera as being distinct, generalists more often preferred a broader genus concept in which Ouratea comprises the genera Campylospermum and Idertia (e.g. Hutchinson et al. 1954), and sometimes even Rhabdophyllum (e.g. Aké Assi \& Gautier 2000, Verdcourt 2005).

The new species published here are part of our on-going research efforts on the systematics of Ouratinae in cooperation with the Senckenberg Research Institute at Frankfurt. Rhabdophyllum was revised recently (Sosef 2008), but notably the taxonomy of Campylospermum is still unclear. The first author is preparing her $\mathrm{PhD}$ thesis on the taxonomy, phylogeny and biogeography of Ochnaceae, with an emphasis on Campylospermum. Most of the novelties resulting from her taxonomic work on the continental African representatives are presented here. Molecular phylogenetic work in progress (Bissiengou, unpubl. data) has not yet led to sufficient resolution in the phylogenetic tree and hence does not yet allow resolving the relationships among the four Ouratinae genera. Being unable to anticipate future phylogenetic results, for now we adopt a conservative approach and adhere to generic concepts based on morphology.

The generic name Gomphia Schreb. [1789] is to be regarded as a synonym of the older Ouratea Aubl. [1775], following a

\footnotetext{
Naturalis Biodiversity Center (section NHN-Wageningen), Generaal Foulkesweg 37, 6703 BL Wageningen, The Netherlands.

2 Biosystematics Group, Wageningen University, Wageningen, The Netherlands.

${ }^{3}$ Herbier National du Gabon, IPHAMETRA - CENAREST, Libreville, Gabon.

* Corresponding author e-mail: Bissiengou_p@yahoo.fr.
}

complex lectotypification (Kanis 1967, Bittrich \& Amaral 1994). Unfortunately, the latter publication was apparently missed by Verdcourt (2005), who followed Kanis (1967) and thus erroneously re-introduced the genus name Gomphia in African botanical literature.

Tropical African Ochnaceae have been treated in various Flora's (Bamps \& Farron 1967, Hutchinson et al. 1954, Robson 1963, Verdcourt 2005). However, species occurring in the Lower Guinean area (part of the Guineo-Congolian floristic region, or phytochorion; White 1979) remain without a proper taxonomic treatment to date. Although Farron $(1965,1968,1985)$ published important contributions to the taxonomy of African Ouratinae, relevant for this area, our knowledge about this group remains highly incomplete. This information gap is seen in many other plant groups and is especially relevant in the light of the fact that the lowland rain forests of the Lower Guinean region (notably those in Cameroon and Gabon) are regarded as the most species-rich of tropical Africa (Mutke et al. 2001, Linder 2001, Küper et al. 2004, Sosef et al. 2006, Estrella et al. 2012, Linder et al. 2012). For this area, taxonomic revisions are indispensable, since in some cases they directly contribute to datasets that help prioritize conservation efforts (e.g. Burgess et al. 2005). The Flore du Gabon production tries to address the knowledge gap (Sosef \& Florence 2007), but its existence as well as the extraordinary species richness of Lower Guinea is further emphasized by the fact that all species in African Ouratinae that have been described during the past 25 years (e.g. Sosef et al. 2007, Bissiengou \& Sosef 2008, this publication) are endemic or sub-endemic to Gabon. Along with the fact that the botanical exploration of Gabon is far from complete (Sosef et al. 2006), this means that still many other novelties may be expected to emerge from Gabon's lush vegetation (see for example Walters et al. 2011).

\section{MATERIALS AND METHODS}

To perform the taxonomic revision of the genus Campylospermum, herbarium material from the following herbaria has been consulted (acronyms follow Thiers 2012): A, B, BAS, BM, BR, 
BRLU, C, COI, E, EA, FHO, G, K, L, LBV, LISU, LY, MA, MO, NEU, P, PRE, S, SRGH, US, WAG, $Z$.

All specimen data have been entered into the BRAHMS (Botanical Research and Herbarium Management System) database of the National Herbarium of the Netherlands (now part of the Naturalis Biodiversity Center). To perform an assessment of the IUCN category of threat for each taxon, the BRAHMS software was used in combination with ArcView 3.3 and the IUCN Red List add-in script developed by Moat (2007). Assignments follow the IUCN guidelines (IUCN Standards and Petitions Subcommittee 2011), but not the advice to set the cell width/height to $2 \mathrm{~km}$. Instead, a sliding scale grid cell width is applied, which is deemed more appropriate for herbarium record data (Moat 2007). We define a 'location' as a single grid cell. All assignments will be send to IUCN for approval in the near future, which is why we characterize them as 'preliminary' for now.

\section{NEW TAXA}

\section{Campylospermum auriculatum Biss., sp. nov. — Fig. 1; Map 1}

Diagnosis - This species resembles $C$. schoenleinianum (Klotzsch) Farron because of its auriculate to deeply cordate leaf base, but differs by the leaf blade being broader in the basal part, and by having caducous stipules, a serrate leaf margin, a flattened peduncle and shorter and more compact racemes of $3-11 \mathrm{~cm}$ long.

Type. Strijk 73 (holo WAG; iso LBV), Gabon, Woleu-Ntem, Bordamur concession area, some $40 \mathrm{~km}$ from WWF-station, N1¹4', E11 53', 10 Oct. 2002.

Understorey treelet up to $6 \mathrm{~m}$ tall. Stipules caducous, $3-5 \mathrm{~mm}$ long. Leaves: petiole $0-2 \mathrm{~mm}$ long; leaf blade elliptic-obovate to oblanceolate, $(9-) 14-24(-31)$ by $(4-) 6-8(-11) \mathrm{cm}$, base auriculate to deeply cordate, often clasping the twig, apex acute, coriaceous to thick leathery, margin serrate, upper surface glossy green, lower surface dull paler green; midrib flattened above, prominent below, main lateral veins $10-20 \mathrm{~mm}$ apart, $16-19$ on either side, curved upward to run parallel to the margin, intermediate lateral veins prominent on both sides, $0-2$ in between each pair of main laterals, tertiary venation scalariform, very distinct on both sides. Inflorescences terminal or rarely axillary, its main axis 12-15(-18) cm long, flattened; racemes 1-6, $3-9(-11) \mathrm{cm}$ long; pairwise scales absent; bracts persistent at the base of the raceme and pedicel, triangular, c. 3-5 mm long; cymules 5-9 $\mathrm{mm}$ apart, 2-4(-6)-flowered. Flowers: pedicel $5-7 \mathrm{~mm}$, articulated at 2-3 $\mathrm{mm}$ from the base; sepals 5, ovate, in flower $7-8$ by $2-3 \mathrm{~mm}$, yellowish green, in fruit persistent and accrescent, $9-10$ by $3-4 \mathrm{~mm}$, bright red; petals 5 , obovate, 7-12 by 3-4 $\mathrm{mm}$, cuneate at base, rounded at apex, bright yellow; stamens 10 , caducous, orange-yellow, filaments less than $1 \mathrm{~mm}$ long, anthers 3-4 $\mathrm{mm}$ long, transversely wrinkled, poricidal; ovary c. $2 \mathrm{~mm}$ wide; style c. $4 \mathrm{~mm}$ long, curved, yellow. Fruits: receptacle a \pm flattened-globose shape, c. $5 \mathrm{~mm}$ wide, orange-red; drupelets 1-3 well developed per receptacle, reniform, c. 8 by $5 \mathrm{~mm}$, black at maturity; cotyledons incumbent, dissimilar in size with a small outer cotyledon.

Distribution - Equatorial Guinea (Rio Muni) and Gabon (Woleu-Ntem province).

Ecology - In primary or secondary forest; on brown clay soil; at 475-600 m altitude.

Phenology - Flowers and mature fruits collected from October to November, flowers also observed in April, which coincides with the two rainy seasons.

Preliminary IUCN conservation status - VU B1/B2ab(ii, iii, iv). $\mathrm{EOO}=6098 \mathrm{~km}^{2}, \mathrm{AOO}=1653 \mathrm{~km}^{2}$, locations $=7$ (cell width $=15.37 \mathrm{~km}$ ). All collections have been made recently (the oldest one is from 1983). The only collection from Equatorial Guinea is from within a protected area (Inselberg at Akuom). The other ten collections from Gabon are from a fairly restricted area where logging companies operate which may lead to a decline in the AOO and/or extent of suitable habitat and hence we propose the 'Vulnerable' category.

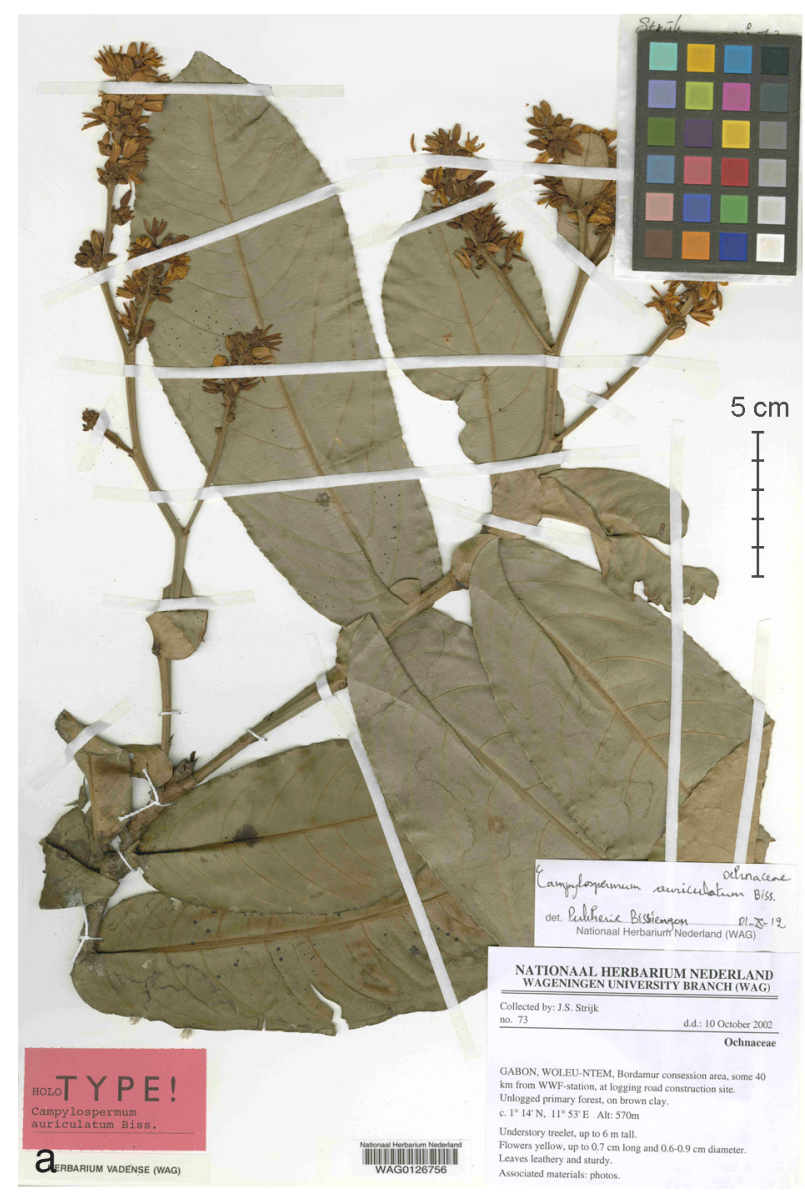

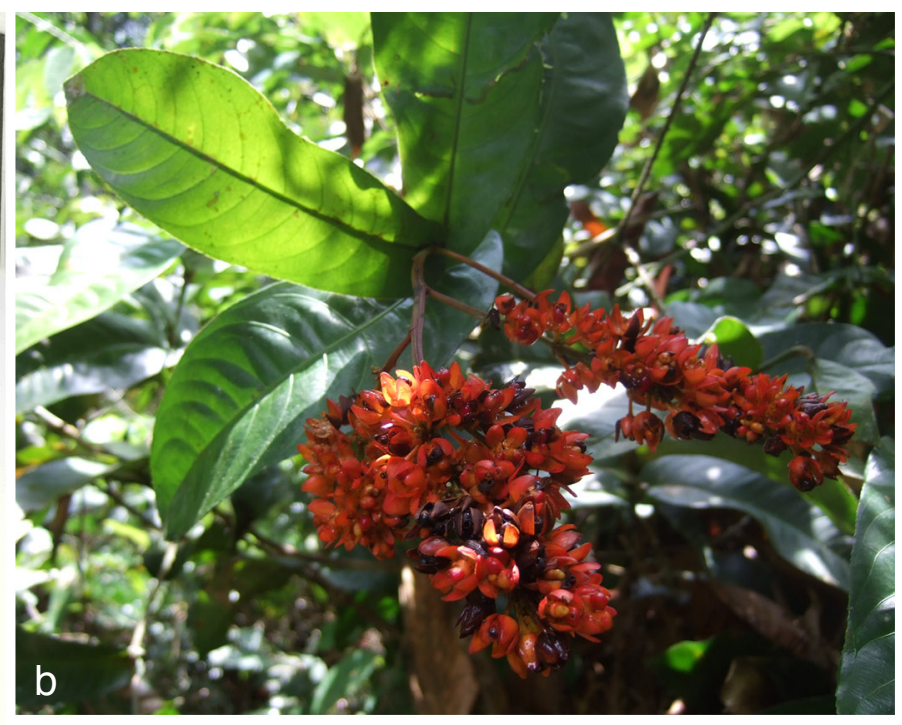

Fig. 1 a. Campylospermum auriculatum Biss. (Strijk 73, holotype WAG); b. Campylospermum auriculatum in fruit. - Photo by Y. Issembé. 


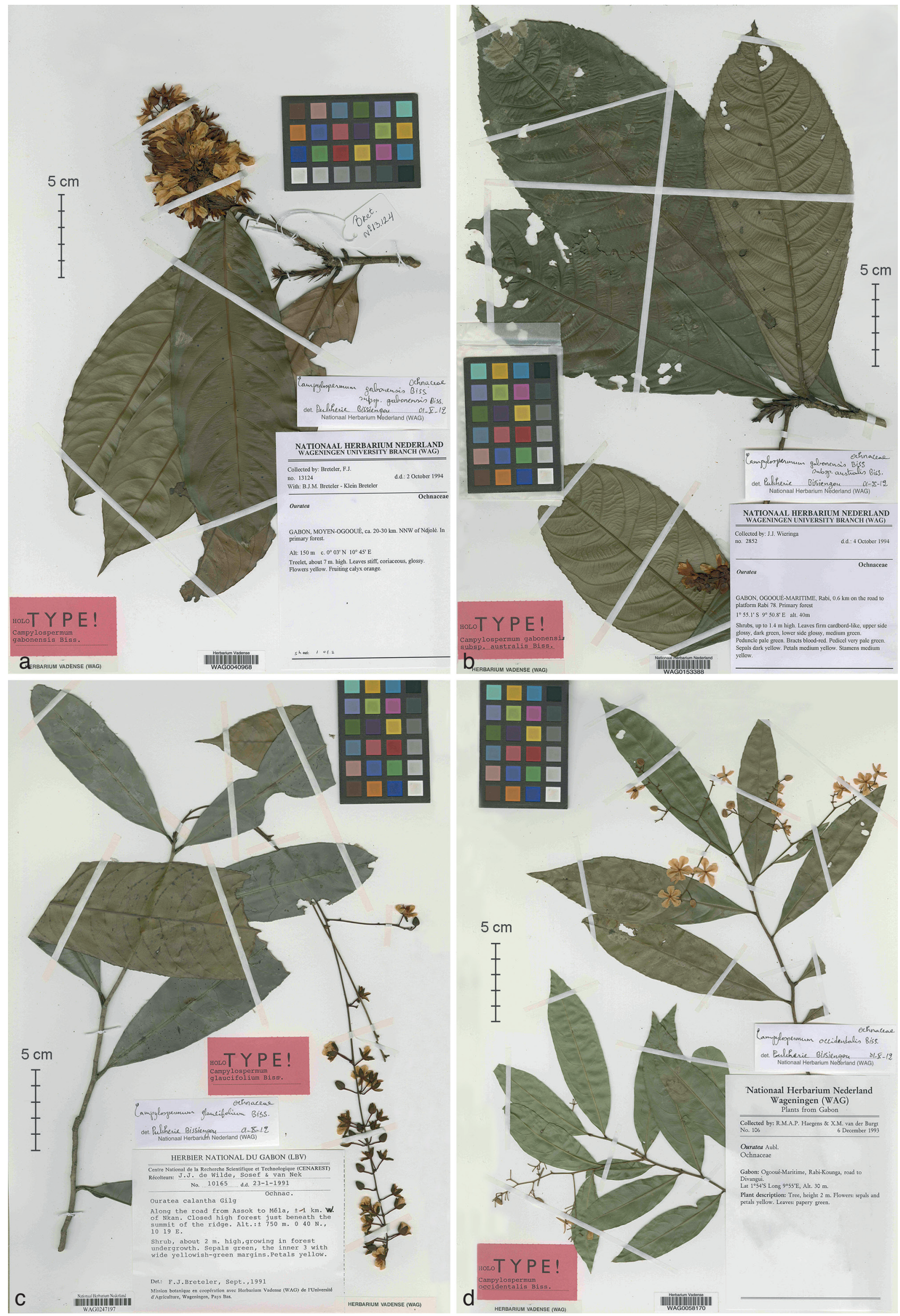

Fig. 2 a. Campylospermum gabonensis Biss.; b. C. gabonensis subsp. australis Biss.; c. C. glaucifolium Biss. d. C. occidentalis Biss. (a: Breteler 13124; b: Wieringa 2852; c: J.J. de Wilde 10165; d: Haegens 106; all holo WAG). 


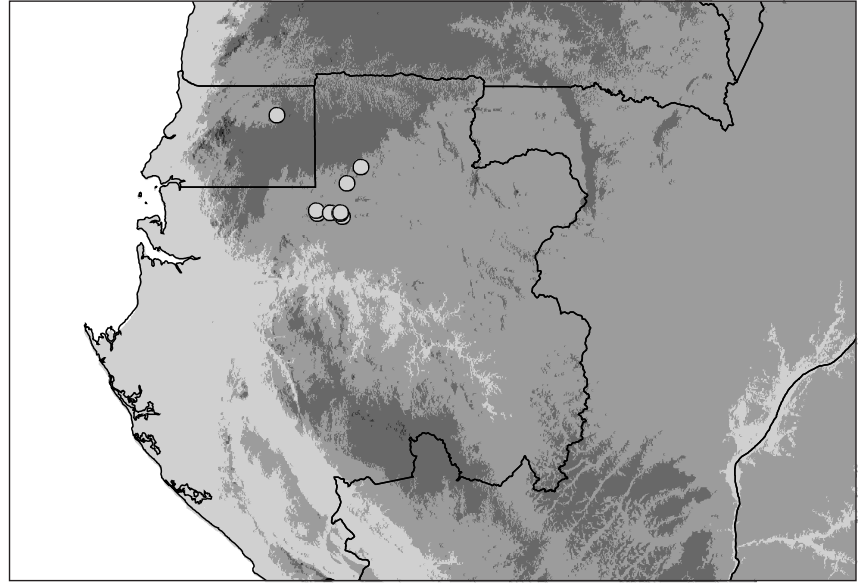

Map 1 Distribution of Campylospermum auriculatum Biss. Background indicates altitude.

Additional material. Equatorial Guinea, Rio Muni, Wele Nzas: Parmentier 358 (BRLU), Inselberg d'Akuom, à $1 \mathrm{~h} 30$ de marche $(6 \mathrm{~km})$ du village de Nzuameyong, à $25 \mathrm{~km}$ d'Anisoc, N1 ${ }^{\circ} 50^{\prime}$ E1055', 600 m, 13 June 1999 (st). - GABON, Woleu-Ntem: Bissiengou 667 (LBV, WAG), c. $8 \mathrm{~km} \mathrm{SSW} \mathrm{of}$ Mitzic, FOREENEX forest exploitation, N042.9' E11³2.0', 547 m, 6 Nov. 2009 (fr); Bissiengou 707 (LBV, WAG), 8.5 km SSW of Mitzic, FOREENEX forest exploitation, $\mathrm{N}^{\circ} 42.5^{\prime} \mathrm{E} 11^{\circ} 31.9^{\prime}, 501 \mathrm{~m}, 6$ Nov. 2009 (fl); Bissiengou 714 (LBV, WAG), $13 \mathrm{~km}$ SE of Mitzic, FOREENEX forest exploitation, road from forestry camp to Madouaka village, N042.4' E11 ${ }^{\circ} 38.2^{\prime}, 480$ m, 7 Nov. 2009 (fl); Bissiengou 730 (LBV, WAG), 13 km SE of Mitzic, FOREENEX forest exploitation, road from forestry camp to Madouaka village, $\mathrm{NO}^{\circ} 42.1^{\prime}$ E11 $38.8^{\circ}, 490$ m, 7 Nov. 2009 (fr); Bissiengou 769 (LBV, WAG), 35 km NNE of Mitzic, forestry road in Bordamur forest exploitation, $2 \mathrm{~km}$ from forestry camp, N102.8' E114⒊3', 545 m, 8 Nov. 2009 (st); Breteler 8797 (LBV, WAG), 30-40 km NE of Saint Germain, E of Okano River, c. N0 ${ }^{\circ} 40^{\prime}$ E $11^{\circ} 40^{\prime}, 475 \mathrm{~m}$, 18 Apr. 1988 (fl, fr); A.M. Louis 377 (K, LBV, WAG), Oveng, 65 km N of road Benguié-Lalara, forest exploitation camp, N042' E11²3', 500 m, 5 Nov. 1983 (fl, fr); Maas 10052 (LBV, WAG), RN 2, S of Mitzic, FOREENEX-concession, N042.8' E11 ${ }^{\circ} 38.9^{\prime}, 503$ m, 30 Oct. 2011 (fl); Reitsma 2493 (WAG), Inventory

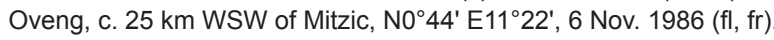

Note - Especially the auriculate to deeply cordate leaf base is highly reminiscent of $C$. schoenleinianum, a species confined to western tropical Africa (from Guinea to Ghana).

\section{Campylospermum gabonensis Biss., sp. nov.}

Diagnosis - Aspecies resembling C. claessensii (De Wild.) Farron, but with persistent, $7-15 \mathrm{~mm}$ long, stipules and an unbranched and compact inflorescence.

Type. Breteler \& Breteler-Klein Breteler 13124 (holo WAG; iso LBV, WAG), Gabon, Moyen-Ogooué, c. 20-30 km NNW of Ndjolé, N003' E1045', 2 Oct. 1994.

\section{subsp. gabonensis - Fig. 2; Map 2}

Tree or treelet, up to $7 \mathrm{~m}$ tall. Stipules persistent, narrowly triangular, 7-15 cm long. Leaves: petiole canaliculated above, 3-7 $\mathrm{mm}$ long; leaf blade narrowly elliptic to narrowly elliptic-obovate, $16-30(-35)$ by $6-10(-11) \mathrm{cm}$, base cuneate to tapering, apex acuminate or sometimes acute, thick leathery to coriaceous, margin serrulate or sometimes entire toward the base, rarely entire, upper surface flat or rarely bullate, dark green, lower surface paler green, both sides glossy, young leaves purplered; midrib flattened above, prominent below, main lateral veins 6-23 mm apart, 14-27 on either side, prominent on both sides, curved upward to run parallel to the margin, intermediate lateral veins not to slightly prominent on both sides, $0-2$ in between each pair of main laterals, tertiary venation scalariform, running perpendicular to the midrib, indistinct on the upper side, slightly distinct on the lower. Inflorescences terminal, unbranched, erect, compact, 3-13 cm long; peduncle robust; pairwise scales

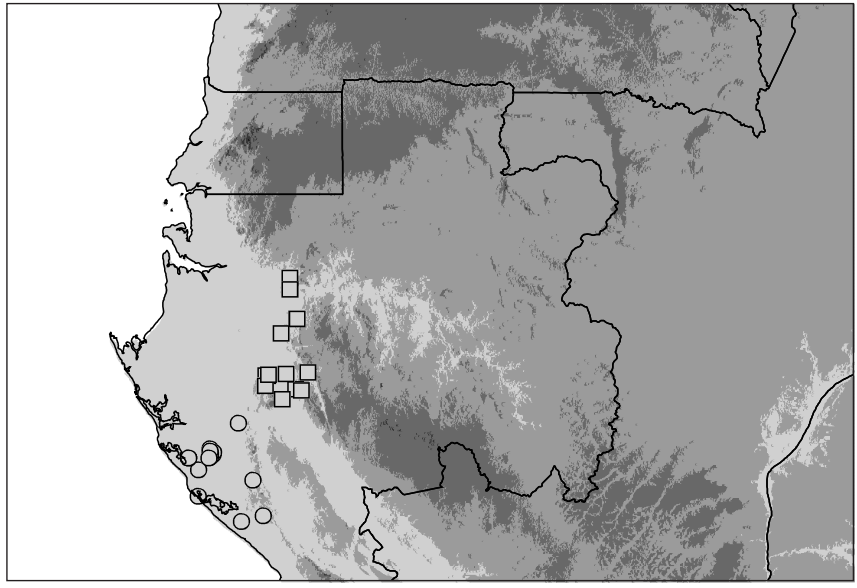

Map 2 Distribution of Campylospermum gabonensis Biss. subsp. gabonensis $(\square)$ and subsp. australis Biss. (O). Background indicates altitude.

persistent at the base of the peduncle, narrowly triangular; bracts persistent at the base of the cymule, triangular, 2-3 mm long; cymules 3-5(-10) mm apart, 4-8-flowered. Flowers: pedicel $5-15 \mathrm{~mm}$, articulated at $3-9 \mathrm{~mm}$ from the base, pale green; sepals 5 , ovate, in flower $7-9$ by $2-3 \mathrm{~mm}$, greenish, in fruit $9-10$ by $3-4 \mathrm{~mm}$, persistent and accrescent, red; petals 5 , obovate, yellow, $10-15$ by $5-9 \mathrm{~mm}$, cuneate at base, rounded at apex; stamens 10, pale yellow, filaments less than $1 \mathrm{~mm}$ long, anthers 5-7 mm long, transversely wrinkled, poricidal; ovary c. $2 \mathrm{~mm}$ wide; style $6-7 \mathrm{~mm}$ long, curved. Fruits: receptacle a \pm flattened-globose shape, 3-4 mm wide, red; drupelets 1-2 well developed per receptacle, ellipsoid, c. 7 by $5 \mathrm{~mm}$, black at maturity; cotyledons incumbent, dissimilar in size with a smaller outer cotyledon.

Distribution - Endemic to Gabon (Moyen-Ogooué and Ngounié provinces).

Ecology - In primary and secondary forest, sometimes along rivers or streams; at 70-400 m altitude.

Phenology - Flowers observed from August to November and in April; fruits collected from October to January.

Preliminary IUCN conservation status - VU B1ab(ii, iii, iv). $\mathrm{EOO}=4476 \mathrm{~km}^{2}, \mathrm{AOO}=2348 \mathrm{~km}^{2}$, locations $=10$ (cell width $=15.32 \mathrm{~km}$ ). All known records of this taxon are from areas exposed to mining and/or logging activities rendering a projected decline in its $\mathrm{AOO}$ and/or quality of the habitat most likely and hence we propose the 'Vulnerable' category.

Additional material. GABON, Moyen-Ogooué: Azizet Issembé 176 (LBV, WAG), Camp Mboumi, Base, c. S0²5' E1050', 16 Aug. 1999 (fl); Breteler 10375 (LBV, WAG), Missanga, 5-15 km NNW of Ndjolé, c. E005' E1045', 11 Nov. 1991 (fl); Breteler 10983 (WAG), 5-30 km NNW of Ndjolé, c. S005' E1045', 21 Apr. 1992 (fl); Breteler 14655 (WAG), M'Boumi, chantier SHM, C. $30 \mathrm{~km} S$ of Ndjolé, on border of the Ogooué river near Ndjolé, $\mathrm{SO}^{\circ} 25^{\prime}$ E10 50 ', 17 Nov. 1998 (st); Breteler 14658 (LBV, WAG), idem; Dibata 66 (LBV, MO, WAG), ENE de Belle Vue, Layon $\times$, S0³5' E10³9', 23 Jan. 1987 (fl). Ngounié: Bissiengou 610 (LBV, WAG), along a forestry road of chantier EFT (Exploitation Forestière de Tsanba) starting at Ndjemba village on Fougamou-Lambaréné road, $\mathrm{S} 1^{\circ} 03.7^{\prime} \mathrm{E} 10^{\circ} 28.6^{\prime}, 129 \mathrm{~m}, 29$ Oct. 2009 (fl); Bissiengou 627 (LBV, WAG), idem, S1ํ10.9' E10²8.4', 165 m, 29 Oct. 2009 (fl); Bissiengou 628 (LBV, WAG), idem; Bissiengou 1432 (LBV, WAG), Sindara, après village Matadi 7 route exploitation forestière EGG (ancien IFL), S1 02.76 ' E1042.50', 72 m, 22 June 2011 (st); Bissiengou 1451 (LBV, WAG), Fougamou, village Nzemba route du chantier forestier EGBD, entrée école, S103.06' E10³0.37', 97 m, 24 June 2011 (st); Bissiengou 1452 (LBV, WAG), idem; Breteler 5725 (WAG), 50 km SE of Lambaréné, C. S1 ${ }^{\circ} 04^{\prime} \mathrm{E} 10^{\circ} 30^{\prime}, 28$ Sept. 1968 (fl); Breteler 14052 (WAG), between Yombi and Fougamou, E slope of Koumounabouali ridge, c. S1 ${ }^{\circ} 20^{\prime} \mathrm{E} 10^{\circ} 40^{\prime}, 22$ Sept. 1997 (st); Leeuwenberg 13617 (WAG), right bank Ngounié R., SE of Sindara, km $17 \mathrm{SW}$ of Chantier Waka, S1 ${ }^{\circ} 13^{\prime} \mathrm{E} 10^{\circ} 49^{\prime}, 400 \mathrm{~m}, 22$ Sept. 1985 (fl); A.M. Louis 1324 (WAG), 2-3 km SE of Forestry Camp Waka situated $\pm 32 \mathrm{~km}$ SE of Sindara, Waka R. Basin, c. S1 ${ }^{\circ} 14^{\prime} \mathrm{E} 10^{\circ} 53^{\prime}, 350 \mathrm{~m}, 12 \mathrm{Dec}$. 1983 (fr); Wieringa 4402 (WAG), $2 \mathrm{~km}$ on the road branching off near lkobey to Magonga, S1 ${ }^{\circ} 01.67^{\prime} \mathrm{E} 10^{\circ} 57.46^{\prime}, 200 \mathrm{~m}, 25 \mathrm{Nov} .2001$ (fr). 
subsp. australis Biss., subsp. nov. - Fig. 2; Map 2

Diagnosis - Like the typical subspecies, but the leaf blade bullate between the lateral veins or rarely flat and the scalariform tertiary veins running perpendicular to the main lateral veins.

Type. Wieringa 2852 (holo WAG; iso BR, LBV, MO), Gabon, OgoouéMaritime, Rabi, $0.6 \mathrm{~km}$ on the road to platform Rabi $78, \mathrm{~S} 1^{\circ} 55.1^{\prime}, \mathrm{E} 9^{\circ} 50.8^{\prime}$, 4 Oct. 1994.

Distribution - Endemic to Gabon (Ogooué-Maritime, western Ngounié and Nyanga provinces).

Ecology - In primary, moist and wet forest, in valleys with small streams; on sandy soil; at 3-350 m altitude.

Phenology - Flowers observed from October to December; fruits collected from October to January.

IUCN conservation status - VU B1/B2ab(ii, iii, iv). EOO = $6862 \mathrm{~km}^{2}, \mathrm{AOO}=1545 \mathrm{~km}^{2}$, locations $=10$ (cell width $=12.43$ $\mathrm{km}$ ). This taxon is known only from 15 recent collections, five of which fall within the Loango National Park and the MoukalabaDoudou National Park. The remaining ten collections originate from logging and oil concessions while even the Loango park is under development threat from Chinese mining companies. Therefore this subspecies is best placed in the category ' $\mathrm{Vul}$ nerable'.

Additional material. GABON, Ngounié: Le Testu 5834 (BR, P), Agouma, c. S1 ${ }^{\circ} 36^{\prime} \mathrm{E} 10^{\circ} 10^{\prime}$, Dec. 1925 (st). Nyanga: Jongkind 5734 (LBV, WAG), Doudou Mountains, Chantier SFN-Bakker, S2³9.2' E10²7.0', 180 m, 22 Nov. 2003 (st). Ogooué-Maritime: Arends 635 (WAG), Monts Doudou, W of Doussala and Réserve de Faune de Moukalaba, c. S2 ${ }^{\circ} 15^{\prime}$ E10 $20^{\circ}, 350$ m, 5 Dec. 1984 (fr); van Bergen 126 (WAG), savannah road to Vera, $32 \mathrm{~km}$ E from junction to Mayonami, S2 ${ }^{\circ} 43.4^{\prime}$ E10¹2.2', 70 m, 21 Nov. 1995 (fr); Breteler 10152 (WAG), Rabi-Kounga, Echira road, c. S2 ${ }^{\circ} 00^{\prime}$ E9 ${ }^{\circ} 50^{\prime}, 27$ Oct. 1991 (fl); Farron $7416(P)$, Koumouloundou, route d'accès au Rembo-Rabi, S2 ${ }^{\circ} 00^{\prime}$ E9 ${ }^{\circ} 36^{\prime}$, 10 June 1970 (fl); Haegens 89 (WAG), Rabi, W of Shell platform 76, S1 ${ }^{\circ} 57^{\prime}$ E951', 30 m, 2 Dec. 1993 (fl); van Nek 117 (WAG), Rabi-E, N of Pechoud Camp, S156.5' E952.9', 26 Oct. 1990 (st); van Nek 289 (LBV, MO, WAG), Rabi-NW, near Rembo Rabi, NW of Rabi site, S1 ${ }^{\circ} 53.7^{\prime}$ E9 ${ }^{\circ} 50.7^{\prime}, 13$ Nov. 1990 (fl); van Nek 560 (LBV, WAG), near Rabi, S157.6' E952.8', 11 Jan. 1991 (fr); Schoenmaker 34 (WAG), Rabi-Kounga, opposite Buzzichelli, S1 ${ }^{\circ} 56^{\prime}$ E9 ${ }^{\circ} 53^{\prime}$, 15 Oct. 1991 (fl); Schoenmaker 134 (WAG), Rabi-Kounga, direction Echira, C. S15ㅇ' E951', 11 Nov. 1991 (fl); J.J.F.E. de Wilde 9843 (LBV, WAG), 30 km $\mathrm{S}$ of Rabi, high bank of an affluent of the Echira River, S2 ${ }^{\circ} 08^{\prime} \mathrm{E9}^{\circ} 43^{\prime}, 15 \mathrm{~m}$, 28 Nov. 1989 (fr); J.J.F.E. de Wilde 11363 (LBV, WAG), Gamba, N'Dogo Lagoon, near Sounga, S2 $25.9^{\prime}$ E9² $42.7^{\prime}, 3$ m, 10 Dec. 1994 (fl).

Notes - This subspecies can be added to the list of taxa endemic to the greater Loango-Rabi area (Wieringa \& Mackinder 2012). It is also an addition to the recently published checklist of Loango National Park (Harris et al. 2012), and provides further evidence for the unique vegetation in this part of Gabon (Wieringa \& Sosef 2011).

Apart from the fact that the material shows a scalariform venation different from that of the typical subspecies, and a tendency to have more obviously bullate leaves, there seem to be no other differentiating characters. This, together with the parapatric distribution of the two entities, made us decide to distinguish the taxon at the subspecies level.

\section{Campylospermum glaucifolium Biss., sp. nov. - Fig. 2; Map 3}

Diagnosis - A species resembling C. calanthum (Gilg) Farron, but with a glaucous upper leaf surface (at least when dry), longer petiole, and a pendulous inflorescence that carries $0-2(-3)$ racemes.

Type. J.J. de Wilde et al. 10165 (holo WAG; iso LBV), Gabon, Estuaire, 1 km W of Nkan, along the road from Assok to Méla, N040', E10¹9', 23 Jan. 1991.

Treelet up to $2 \mathrm{~m}$ tall. Stipules caducous, $2-3 \mathrm{~mm}$ long. Leaves: petiole $7-15(-20) \mathrm{mm}$ long, canaliculate above; leaf blade narrowly elliptic to narrowly elliptic-obovate, $13-25(-30)$ by $4-7$ $(-8) \mathrm{cm}$, base cuneate, apex acuminate, leathery to coriaceous, margin serrulate, upper surface glossy, dark green but turning glaucous when dry, lower surface pale green, young leaves reddish; midrib generally prominent on both sides, main lateral veins $10-15 \mathrm{~mm}$ apart, $14-16$ on either side, slightly prominent above, prominent below, curved upward to run parallel to the margin, tertiary venation scalariform, running perpendicular to the midrib thus causing the formation of a decreasing series of intermediate lateral veins, indistinct above, distinct below. Inflorescences terminal, pendulous, (9-)15-33 cm long; peduncle slender; racemes $0-2(-3), 3-6(-10) \mathrm{cm}$ long; pairwise scales persistent at the base of peduncle; bracts caducous, triangular, c. 2-3 mm long; cymules $0.5-1(-1.5) \mathrm{cm}$ apart, 1-4-flowered. Flowers: pedicel 3-12 $\mathrm{mm}$, articulated at $1-3 \mathrm{~mm}$ from the base; sepals, ovate, in flower $6-7$ by $2-3 \mathrm{~mm}$, green-yellowish, in fruit $8-9$ by $3-4 \mathrm{~mm}$, persistent and accrescent, bright red; petals obovate, 7-9 by $4-5 \mathrm{~mm}$, shortly clawed at base, rounded at apex, bright yellow; stamens 10 , filaments less than $1 \mathrm{~mm}$ long, anthers 5-6 mm long, transversely wrinkled, poricidal; ovary c. $2 \mathrm{~mm}$ wide; style slender, 6-7 mm long. Fruits: receptacle a \pm flattened-globose shape, c. $3 \mathrm{~mm}$ wide, red; drupelets 1-4 well developed per receptacle, reniform, black at maturity; cotyledons accumbent, similar in size.

Distribution - Continental Equatorial Guinea (Rio Muni), Gabon and south-western Republic of the Congo (Niari).

Ecology - In primary and secondary forest, on creek banks and adjacent to swampy areas; at 210-1000 m altitude.

Phenology - Flowers collected in January, April, July and August; fruits collected from March to May and in August.

Preliminary IUCN conservation status - LC. EOO $=72,683$ $\mathrm{km}^{2}, \mathrm{AOO}=23,157 \mathrm{~km}^{2}$, locations $=9$ (cell width $=50.79 \mathrm{~km}$ ). This species, although being sub-endemic to Gabon, has a fairly wide distribution and hence its $\mathrm{EOO}$ and $\mathrm{AOO}$ are comparatively large, and above the IUCN thresholds. Potential future threats could come from habitat destruction (logging or land transformation) but a fair number of populations are located within protected areas (PN de Monte Alen, Monts de Cristal NP, Waka NP, Lopé Reserve). Therefore, the category of 'Least Concern' is here proposed.

Additional material. Congo (Brazzaville), Niari: Bissiengou 1326 (LBV, WAG), route Malinga-Divénié, $4 \mathrm{~km}$ du village Mollo, S2 $29.64^{\prime} \mathrm{E} 12^{\circ} 09.61$ ', 480 m, 13 June 2011 (st). - Equatorial Guinea, Rio Muni, Centro Sur: Desmet, G. 242 (BRLU), Mundung 'Les 4 montagnes', N1 ${ }^{\circ} 38^{\prime} \mathrm{E} 10^{\circ} 11^{\prime}, 1000 \mathrm{~m}$, 8 Jan. 2003 (fr); Ngomo 418 (BRLU), Parc National de Monte Alen, c. N140' E10¹7', 30 July 1998 (fl); Pérez Viso 1139 (MA), Parque Nacional de Monte Alén, Esamalang, camino hacia Mondung, c. N1³3' E10¹2', 13 May 1999 (fr); Senterre 4122 (BRLU), Parc National de Monte Alen, 11 km à l'Est de la cabaña de Mosumo, N1³6.4' E1008.5', 12 July 2003 (st); Wilks 1796 (LBV, WAG), Monts de Cristal, 10 km ENE d'Okuamkos, N1 ${ }^{\circ} 10^{\prime} \mathrm{E} 10^{\circ} 16^{\prime}$, 12 Aug. 1988 (fl). - GABON, Estuaire: J.J.F.E. de Wilde 10257 (LBV, WAG),

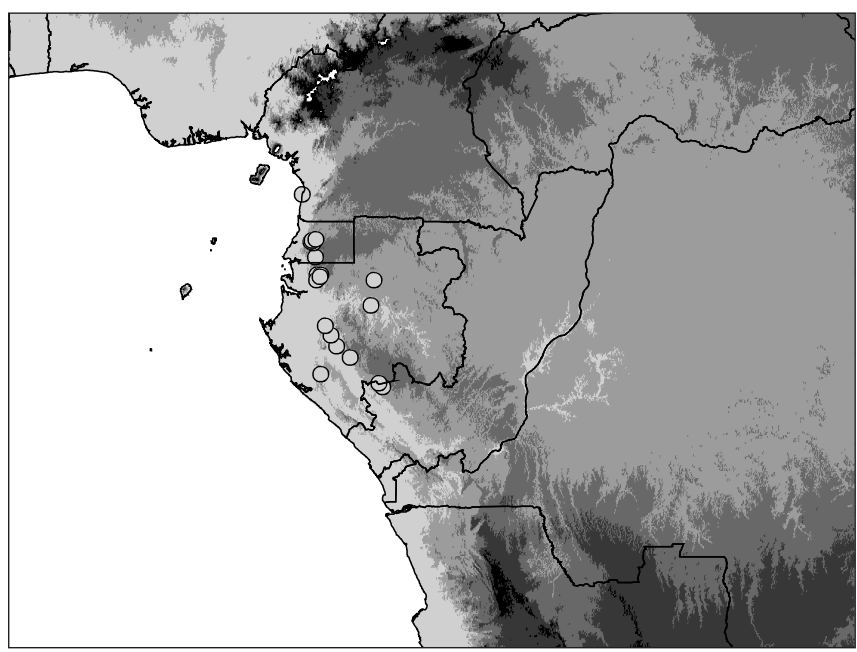

Map 3 Distribution of Campylospermum glaucifolium Biss. Background indicates altitude. 
Crystal Mountains, $25 \mathrm{~km}$ on the road Tchimbélé-Kinguélé, N0 $311^{\prime} \mathrm{E} 10^{\circ} 18^{\prime}$, 360 m, 26 Jan. 1991 (fl). Ngounié: A.M. Louis 3058 (LBV, WAG), route chantier Leroy Massika entre Mouila et Yeno, S1 ${ }^{\circ} 40^{\prime} \mathrm{E} 11^{\circ} 15^{\prime}, 600$ m, 27 Apr. 1989 (fr); Bissiengou 1343 (LBV, WAG), route Malinga-Rebé, S2²3.07' E12 03.35', 489 m, 14 June 2011 (st); Bissiengou 1436 (LBV, WAG), Sindara, après village Matadi 7 route exploitation forestière EGG (ancien IFL), S1ํ⒉26' E1042.47', 49 m, 22 June 2011 (st); Wieringa 5192 (LBV, WAG), upper Waka area, $13 \mathrm{~km}$ on IFL forestry road B2, S1 ${ }^{\circ} 20.5^{\prime} \mathrm{E} 10^{\circ} 52.2^{\prime}$, 180 m, 31 Mar. 2004 (fr). Ogooué-Ivindo: Bissiengou 1056 (LBV, WAG), Nord-Est du parc de la Lopé, $25 \mathrm{~km}$ du carrefour qui mène à l'ancien Booué Bac, S0¹1.42' E11ํ50.05', 251 m, 6 Mar. 2010 (fr); Dibata 117 (MO, WAG), Chantier Koumameyong, côté rivière-Marécage à raphia, c. N0 ${ }^{\circ} 31^{\prime}$ E11 ${ }^{\circ} 55^{\prime}$, Mar. 1987 (fr). Ogooué-Maritime: van Valkenburg 3162 (BR, LBV, MO, WAG), old logging road leading southward from chantier CBG Peni, S2 ${ }^{\circ} 07.766^{\prime} \mathrm{E} 10^{\circ} 24.95^{\prime}, 210$ m, 22 Apr. 2005 (fl). Woleu-Ntem: Bissiengou 961 (LBV, WAG), Parc des Monts de Cristal, le long de la rivière Mbé, piste après la case picnic sur la droite, c. N0³7' E10²4', 13 Feb. 2010 (st); Wieringa 500 (BR, C, LBV, MO, PRE, WAG), Crystal mountains, $5.5 \mathrm{~km}$ NNE of Tchimbélé, N040' E10²5', 31 Jan. 1990 (fl).

\section{Campylospermum occidentalis Biss., sp. nov. - Fig. 2; Map 4}

Diagnosis - A species similar to C. paucinervatum Sosef, but leaf blade papery, with an acuminate apex, entire to serrulate margin and 7-11 main lateral veins on either side of the midrib; inflorescence lax, 4-8(-12) cm long, with 1-4(-6) racemes of $1-7(-11) \mathrm{cm}$ long; pedicels $10-15 \mathrm{~mm}$, articulating at $2-5 \mathrm{~mm}$ from the base.

Type. Haegens \& v.d. Burgt 106 (holo WAG; iso LBV), Gabon, OgoouéMaritime, Rabi-Kounga, road to Divangui, S154', E955', 6 Dec. 1993.

Treelet up to $4 \mathrm{~m}$ tall. Stipules caducous, $2-3 \mathrm{~mm}$ long. Leaves: petiole $2-5 \mathrm{~mm}$ long; leaf blade narrowly elliptic to narrowly elliptic-obovate, $6-15$ by $1.5-4.5 \mathrm{~cm}$, base cuneate, apex acuminate, papery, margin entire to serrulate, glossy dark green above, paler green below; midrib slightly prominent above, prominent below, main lateral veins $9-10 \mathrm{~mm}$ apart, $7-11$ on either side, curved upward to run parallel to the margin, tertiary venation distinct on both sides, scalariform, running perpendicular to the midrib thus causing the formation of a series of slightly prominent intermediate lateral veins. Inflorescences terminal, lax, 4-8(-12) cm long; peduncle slender; racemes $1-4(-6), 1-7(-11) \mathrm{cm}$ long, held \pm horizontally, not seldom with secondary branches; pairwise scales at the base of peduncle absent; bracts early caducous; cymules (5-)10-15 mm apart, 1-2(-3)-flowered. Flowers: pedicel 4-10(-15) mm, articulated at $1-6 \mathrm{~mm}$ from the base; sepals ovate, in flower $5-7$ by $2-3$ $\mathrm{mm}$, greenish yellow, in fruit $6-7$ by $3-3.5 \mathrm{~mm}$, persistent and accrescent, red; petals obovate, $5-11$ by $4-7 \mathrm{~mm}$, cuneate at base, rounded to emarginate at apex; stamens 10, yelloworange, filaments less than $1 \mathrm{~mm}$ long, anthers 3-4 mm long;

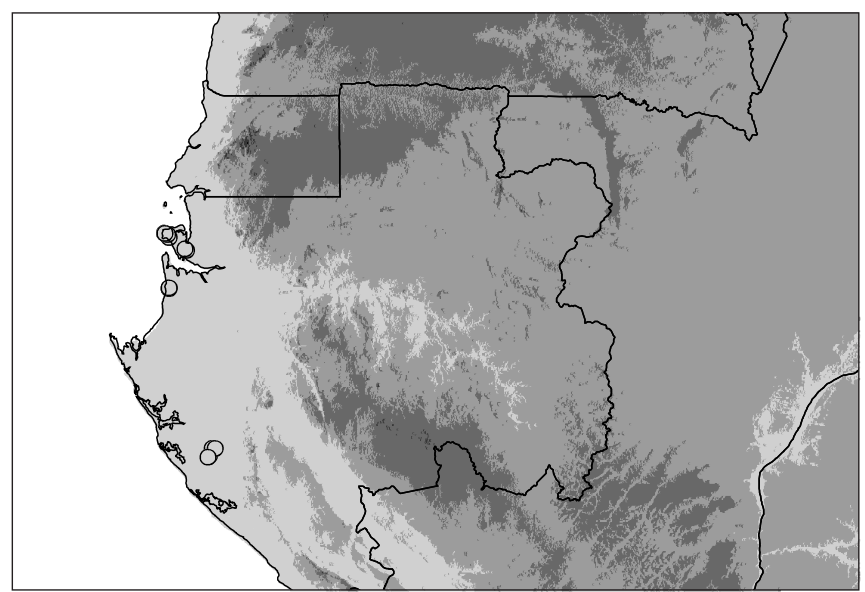

Map 4 Distribution of Campylospermum occidentalis Biss. Background indicates altitude. ovary c. $2 \mathrm{~mm}$ wide; style slender, curved, c. $4 \mathrm{~mm}$ long. Fruits: receptacle a \pm flattened-globose shape, c. $3 \mathrm{~mm}$ wide, red; drupelets $1-3$ well developed per receptacle, ellipsoid, c. 8 by $5 \mathrm{~mm}$, orange to orange-red at maturity; cotyledons incumbent, similar in size.

Distribution - Endemic to Gabon, only found in the coastal plain, in the Ogooué-Maritime (Rabi-Kounga) and Estuaire (Mondah forest and Bikele) provinces.

Ecology - Primary and secondary, moist forest, near swampy areas; on sandy soil; at 5-30 m altitude.

Phenology - Flowers collected from August to November, coinciding with the end of the long dry season and start of the main rainy season; mature fruits from November to December.

IUCN conservation status - VU. B1ab(ii, iii, iv). EOO $=5959$ $\mathrm{km}^{2}, \mathrm{AOO}=3388 \mathrm{~km}^{2}$, locations $=4$ (cell width $=29.10 \mathrm{~km}$ ). This species seems to have a disjunct distribution, but this is uncertain because the area between the two occupied areas is not well explored. In a situation involving a disjunct distribution the sliding scale grid size method leads to an overly large estimation of especially the AOO. Some of the occurrences in the vicinity of the capital Libreville are under threat of habitat destruction due to urbanization and overexploitation. This is likely to lead to a decline in the area of occupancy and/or number of populations or even extent of suitable habitat and hence we propose the category 'Vulnerable'.

Additional material. GABON, Estuaire: A.M. Louis 1201 (WAG), secondary forest $\pm 17 \mathrm{~km} \mathrm{E}$ of Libreville, S of Bikelé village, N0 ${ }^{\circ} 23^{\prime}$ E9 ${ }^{\circ} 35^{\prime}, 7$ Dec. 1983 (fr); Bissiengou 815 (LBV, WAG), Mondah forest, parcelle des conservateurs, No $35^{\prime} \mathrm{E}^{\circ} 20^{\prime}, 10$ Nov. 2009 (fl); Breteler \& J.J.F.E. de Wilde 386 (BR, C, $\mathrm{K}, \mathrm{LBV}, \mathrm{MO}, \mathrm{P}, \mathrm{PRE}, \mathrm{SRGH}, \mathrm{WAG}$ ), Mondah forest, $25 \mathrm{~km}$ along the road Libreville-Cap Esterias, N0³2' E9 ${ }^{\circ} 23^{\prime}, 5$ m, 2 Sept. 1978 (fl); de Saint Aubin 2076 (P), 18 km E de Libreville, c. N0²4' E9³4', Oct. 1961 (fl); Reitsma 1328 (MA, WAG), between Cap Santa Clara and Cap Esterias, N0 ${ }^{\circ} 34^{\prime}$ E9 ${ }^{\circ} 22^{\prime}, 15$ Aug. 1985 (fl); Wilks 1632 (MO, WAG), Forêt de Mondah, N0³5' E9²0', 16 Sept. 1987 (fl, fr); Wilks 2090 (LBV, MO, P, WAG), Nyonyie survey, around 1600 m on transect S, S002.9' E9²3.0', 3 July 1990 (fl, fr); Wilks 2097 (MO, WAG), Nyonyie survey, $2710 \mathrm{~m}$ on transect S, S003.5' E9²3.0', 4 July 1990 (fl). Ogooué-Maritime: Breteler 10161 (LBV, WAG), Rabi-Kounga, Echira road, C. $\mathrm{S} 2^{\circ} 00^{\prime} \mathrm{E} 9^{\circ} 50^{\prime}, 27$ Oct. 1991 (fl); J.J.F.E. de Wilde 9725 (WAG), $1 \mathrm{~km}$ on the road Rabi-Divangui, S1 ${ }^{\circ} 54^{\prime}$ E9 ${ }^{\circ} 53^{\prime}, 25$ Nov. 1989 (fr); Schoenmaker 135 (WAG), Rabi-Kounga, direction Echira, C. S1ํ59' E951', 11 Nov. 1991 (fl).

\section{NEW COMBINATIONS}

\section{Campylospermum andongensis (Hiern) Biss., comb. nov.}

Ouratea reticulatum (P.Beauv.) Engl. ex Gilg var. andongensis Hiern, Cat. Afr. PI. 1 (1896) 122. - Monelasmum andongensis (Hiern) Tiegh. (1902) 328. - Ouratea andongensis (Hiern) Exell (1927) 58. — Type: Welwitsch 4604 (holo LISU; iso BM), Angola, Pungo Andongo, 1857.

\section{Campylospermum costatum (Tiegh.) Biss., comb. nov.}

Monelasmum costatum Tiegh., Ann. Sci. Nat., Bot., ser. 8, 16 (1902) 333. Campylospermum vogelii (Hook.f.) var. costatum (Tiegh.) Farron (1965) 403. - Type: Zenker 1762 (holo P; iso B, COI, G, K, L, LY, P, S, WAG), Cameroon, Bipinde, 1898.

\section{Campylospermum glomeratum (Tiegh.) Biss., comb. nov.}

Monelasmum glomeratum Tiegh., Ann. Sci. Nat., Bot., ser. 8, 16 (1902) 330. Type: Thollon 140 (holo P; iso A, FHO, K), Gabon, Haut Ogooué, Feb. 1895.

Note - The name Ouratea dusenii Engl. \& Gilg, published in 1903, has been used most often in literature as the correct name for this species. Recently, Bissiengou \& Sosef (2008) transferred that name to the genus Campylospermum. However, it now turns out that the name Monelasmum glomeratum Tiegh. (with type specimen Thollon 140) refers to the same taxon and is thus also available. Since it was published in 1902, hence one year before $O$. dusenii, Monelasmum glomeratum Tiegh. has priority which necessitates the new combination C. glomeratum (Tiegh.) Biss. 
Campylospermum longestipulatum (De Wild.) Biss., comb. nov.

Ouratea longestipulata De Wild., PI. Bequaert. 4 (1929) 492. — Type: Zenker 3577 (holo BR; iso E, G, S, US), Cameroon, Bipinde, 1908.

\section{Campylospermum lunzuensis (N.Robson) Biss., comb. nov.}

Ouratea lunzuensis N.Robson, Bol. Soc. Brot., ser. 2, 36 (1962) 38. Gomphia lunzuensis (N.Robson) Verdc. (2005) 47. - Type: Bullock 3877 (holo K; iso BR, K), Zambia, Lunzua River, 19 miles W of Abercorn, 1951.

\section{Campylospermum lutambensis (Sleumer) Biss., comb. nov.}

Ouratea lutambensis Sleumer, Repert. Spec. Nov. Regni Veg. 39 (1936) 278. - Gomphia lutambensis (Sleumer) Verdc. (2005) 52. - Type: Schlieben 6110 (holo B†; iso BR, G, Z), Tanzania, $50 \mathrm{~km} \mathrm{W.} \mathrm{Lindi,} \mathrm{Lake} \mathrm{Lutamba,}$ Noto Plateau, 9 Mar. 1935.

\section{Campylospermum nutans (Hiern) Biss., comb. nov.}

Ouratea reticulata (P.Beauv.) Engl. ex Gilg var. nutans Hiern, Cat. Afr. PI. 1 (1896) 123. - Monelasmum nutans (Hiern) Tiegh. (1902) 328. - Ouratea nutans (Hiern) Exell (1927) 59. - Type: Welwitsch 4606 (holo BM; iso K), São Tomé and Príncipe, Pico de Papagaio, Sept. 1853.

\section{Campylospermum plicatum (Tiegh.) Biss., comb. nov.}

Monelasmum plicatum Tiegh., J. Bot. (Morot) 16 (June 1902) 202. — Type: Griffon du Bellay 296 (holo P), Gabon, Pyrat, Oct. 1863.

\section{Campylospermum warneckei (Gilg ex Engl.) Biss., comb. nov.}

Ouratea warneckei Gilg ex Engl., Veg. Erde 9, Die Pflanzenwelt Afrikas 3, 2 (1921) 490. - Type: Warnecke 468 (holo Z; iso BM, E, EA, K), Tanzania, Amani, 1907.

Acknowledgements The following herbaria are kindly acknowledged for their support of this study by making their material available, either on loan or by direct consultation in the respective institutes: $A, B, B A S, B M, B R$, BRLU, C, COI, E, EA, FHO, G, K, L, LBV, LISU, LY, MA, MO, NEU, P, PRE, $\mathrm{S}, \mathrm{SRGH}$, US, WAG, Z. This study is part of a Sandwich PhD scholarship project funded by Wageningen University. Visits to the herbaria $\mathrm{P}$ en $\mathrm{K}$ were possible thanks to financial support from the Alberta Mennega Foundation and the Foundation Hugo de Vries-Fonds. Additional funding was obtained from the Sud Expert Plantes (SEP) and African-Caribbean-Pacific Forest Research Network (ACP-FORENET) programs, respectively to be able to work at the Wageningen herbarium and for fieldwork in Gabon. During her fieldwork, the first author acknowledges the guidance from Dr. Frans J. Breteler (WAG) and highly useful assistance from Valentin Boulanga, Jean Noel Boussiengui, Estelle Pauline Ngombou Mamadou, Raoul Nyangadouma, Christelle Roseline Nyangala and Thomas Nzabi (all LBV) and from Olivier Valerie Séné Belinga (YA)

\section{REFERENCES}

Aké Assi L, Gautier L. 2000. Deux combinaisons nouvelles dans les genres Ouratea Aubl. (Ochnaceae) et Synsepalum (A.DC.) Daniell (Sapotaceae) de la flore africaine. Candollea 55: 281-282.

Bamps P, Farron C. 1967. Ochnaceae. Flore du Congo, du Rwanda et du Burundi. Jardin botanique national de Belgique, Bruxelles.

Bissiengou P, Sosef MSM. 2008. Novitates Gabonenses 69. A new endemic species of and a new combination in Campylospermum (Ochnaceae). Blumea 53: 627-631.

Bittrich V, Amaral MCE. 1994. Lectotypification of Gomphia Schreb. (Ochnaceae). Taxon 43: 89-93.

Burgess N, Küper W, Mutke J, Brown J, Westaway S, et al. 2005. Major gaps in the distribution of protected areas for threatened and narrow range Afrotropical plants. Biodiversity and Conservation 14: 1877-1894.

De la Estrella M, Mateo RG, Wieringa JJ, Mackinder B, Muñoz J. 2012. Legume diversity patterns in West Central Africa: Influence of species biology on distribution models. PLoS ONE 7, 7: e41526. doi:10.1371/journal.pone.0041526.

De Wildeman É. 1929. Plantae Bequaertianae 4, 4. Buyens, Gand.

Engler A. 1921. Die Pflanzenwelt Afrikas 3, 2. In: Engler A, Drude O (eds), Die Vegetation der Erde IX: 1-878. Engelmann, Leipzig.

Exell AW. 1927. Mr John Gossweiler's plants from Angola and Portugese Congo. Journal of Botany 65, Supplement 1: 25-80.
Farron C. 1965. Les genres Rhabdophyllum van Tiegh. et Campylospermum van Tiegh. (Ochnaceae) en Afrique tropicale (Note préliminaire). Bulletin du Jardin Botanique de l'État 35: 389-405.

Farron C. 1968. Contributions à la taxonomie des Ourateeae d'Afrique. Candollea 23: 177-228.

Farron C. 1985. Les Ouratinae (Ochnaceae) d'Afrique continentale. Cartes de distribution et clés de détermination de tous les genres et espèces. Botanica Helvetica 95: 59-72.

Harris DJ, Armstrong KE, Walters GM, Wilks C, Mouandza Mbembo J-C, et al. 2012. Phytogeographical analysis and checklist of the vascular plants of Loango National Park, Gabon. Plant Ecology and Evolution 145, 1: 242-257. Hiern WP. 1896. Catalogue of the African plants collected by Dr. Friedrich Welwitsch, volume 1, 1. Trustees of the British Museum, London.

Hutchinson J, Dalziel JM, Keay RWJ. 1954. Flora of West tropical Africa, vol. 1, 1. 2nd ed. Crown Agents for Oversea Governments and Administrations, London.

IUCN Standards and Petitions Subcommittee. 2011. Guidelines for using the IUCN Red List Categories and Criteria. Version 9.0. The Standards and Petitions Subcommittee. Downloaded Oct. 2012 from http://www.iucnredlist.org

Kanis A. 1967. The typification of Walkera Schreb. (1789) and Gomphia Schreb. (1789) (Ochnaceae). Taxon 16: 418-423.

Kanis A. 1968. A revision of the Ochnaceae of the Indo-Pacific area. Blumea 16: $1-82$.

Küper W, Sommer JH, Lovett JC, Mutke J, Linder HP, et al. 2004. Africa's hotspots of biodiversity redefined. Annals of the Missouri Botanical Garden 91: $525-535$

Linder HP. 2001. Plant diversity and endemism in sub-Saharan tropical Africa. Journal of Biogeography 28: 169-182.

Linder HP, de Klerk HM, Born J, Burgess ND, Fjeldså J, Rahbek C. 2012. The partitioning of Africa: statistically defined biogeographical regions in sub-Saharan Africa. Journal of Biogeography 39: 1189-1205.

Moat J. 2007. Conservation assessment tools extension for ArcView 3x, version 1.2. GIS Unit, Royal Botanic Gardens, Kew. Available at: http://www rbgkew.org.uk/gis/cats

Mutke J, Kier G, Braun G, Schultz C, Barthlott W. 2001. Patterns of African vascular plant diversity - a GIS based analysis. Systematics and Geography of Plants 71: 1125-1136.

Robson N. 1962. New and little known species from the Flora Zambesiaca area, XI. Boletim da Sociedade Broteriana, 2nd series, 36: 3-39.

Robson NKB. 1963. Ochnaceae. In: Exell AW, Fernandes A, Wild H (eds), Flora Zambesiaca 2, 1: 224-262. Crown Agents for Oversea Governments and Administrations, London.

Sastre C. 1988. Synopsis generis Ouratea Aublet (Ochnaceae). Bulletin du Muséum national d'Histoire naturelle, Paris, $4 \mathrm{e}$ série, section $\mathrm{B}$ Adansonia 10: $47-67$.

Sleumer H. 1936. Vermischte Diagnosen. III. Repertorium Specierum Novarum Regni Vegetabilis 39: 274-282.

Sosef MSM. 2008. Révision du genre africain Rhabdophyllum Tiegh. (Ochnaceae), avec sa distribution au Cameroun et au Gabon. Adansonia, sér. 3, 30, 1: 119-135

Sosef MSM, Florence J. 2007. The Flore du Gabon revitalized with a checklist and database. In: Achoundong G (ed), XVIIth AETFAT Congress, 26 February - 2 March 2007: 130. Herbier National du Cameroun, Yaoundé.

Sosef MSM, Harris DJ, Armstrong KE. 2007. Novitates Gabonenses 64 A new species of Campylospermum (Ochnaceae) from coastal Gabon. Blumea 52: 15-19.

Sosef MSM, Wieringa JJ, Jonkgind $\mathrm{CCH}$, Achoundong G, Azizet Issembé Y, et al. 2006. Check-list des plantes vasculaires du Gabon / Checklist of gabonese vascular plants. Scripta Botanica Belgica 35. National Botanic Garden of Belgium, Meise.

Thiers, B. [Continuously updated]. Index Herbariorum: A global directory of public herbaria and associated staff. New York Botanical Garden's Virtual Herbarium. http://sweetgum.nybg.org/ih/

Van Tieghem P. 1902. Sur les Ochnaceae. Annales des Sciences Naturelles, Botanique, série 8, 16: 161-416

Verdcourt B. 2005. Ochnaceae. In: Beentje HJ, Ghazanfar SA (eds), Flora of Tropical East Africa. Royal Botanic Gardens, Kew.

Walters G, Dauby G, Stévart T, Dessein S, Niangadouma R, Lachenaud O. 2011. Novitates Gabonenses 80. Additions and corrections to the flora of Gabon. Edinburgh Journal of Botany 68: 423-442.

White F. 1979. The Guineo-Congolian region and its relationship to other phytochoria. Bulletin du Jardin Botanique National de Belgique 49: 11-55. Wieringa JJ, Mackinder BA. 2012. Novitates Gabonensis 79: Hymenostegia elegans and $\mathrm{H}$. robusta spp. nov. (Leguminosae - Caesalpinioideae) from Gabon. Nordic Journal of Botany 30: 144-152.

Wieringa JJ, Sosef MSM. 2011. The applicability of Relative Floristic Resemblance to evaluate the conservation value of protected areas. Plant Ecology and Evolution 144: 242-248. 